\title{
Three-dimensional bone modeling of forelimb joints in New Zealand Rabbit: A Micro-Computed Tomography study
}

\author{
Remzi Orkun AKGÜN ${ }^{1, a, ~}$, İsmail Önder ORHAN ${ }^{2, b}$, Okan EKIMM $^{2, c}$ \\ ${ }^{1}$ Cankiri Karatekin University, Faculty of Dentistry, Department of Basic Sciences, Cankiri, Turkey; ${ }^{2}$ Ankara University, Faculty of \\ Veterinary Medicine, Department of Anatomy, Ankara, Turkey \\ aORCID: 0000-0001-6648-7059; bORCID: 0000-0003-3006-4657; ' ${ }^{\mathrm{O}}$ ORCID: 0000-0002-3322-4161. \\ ${ }^{\square}$ Corresponding author: roakgun@karatekin.edu.tr \\ Received date: 08.07.2020 - Accepted date: 24.11.2020
}

\begin{abstract}
In this study, it was aimed to obtain 3-dimensional (3D) digital and printed models of healthy forelimb joints using micro-computed tomography $(\mu \mathrm{CT})$ technique in New Zealand Rabbit, which is frequently preferred in experimental orthopedic studies. Moreover, it was aimed to provide morphometric measurements on the shoulder and elbow joints over 3D digital models. A total of 14 adults ( 7 female, 7 male) New Zealand Rabbits were used in the study. After imaging the forelimbs with the $\mu$ CT device, $3 \mathrm{D}$ digital and printed models were obtained. Biometric measurements of shoulder and elbow joints were performed over 3D digital models and the data obtained from female and male rabbits were evaluated statistically. The anatomical structure on the 3D joint models was very detailed due to the low section thickness and high detector quality. 3D printed models produced as a result of the 3D printing process were quite durable, odorless, and clean. No anatomical differences were observed between 3D printed models and 3D digital models. In this study, it is thought that the anatomical and morphometric data obtained from laboratory rabbits will contribute to scientists take part both in experimental orthopedic intervention and clinical anatomy education.
\end{abstract}

Keywords: Forelimb joints, laboratory rabbit, micro-computed tomography, morphometry, three-dimensional reconstruction.

\section{Yeni Zelanda Tavşanı’ında ön bacak eklemlerinin üç boyutlu kemik modellenmesi: Mikro Bilgisayarlı Tomografi çalışması}

Özet: Bu çalışmada, deneysel ortopedik çalışmalarda sıklıkla tercih edilen Yeni Zelanda Tavşanı'nda sağlıklı ön bacak eklemlerinin mikro bilgisayarlı tomografi $(\mu \mathrm{BT})$ tekniği ile elde edilen görüntülerinden 3B dijital modellerinin oluşturulması, modeller üzerinde omuz ile dirsek eklemlerine ait morfometrik ölçümlerin sağlanması ve bu modellerden 3B yazıcılar kullanılarak 3B baskı modellerinin üretilmesi amaçlanmıştır. Çalışmada toplamda 14 adet (7 dişi, 7 erkek) erişkin Yeni Zelanda Tavşanı kullanıldı. Ön bacakları $\mu \mathrm{BT}$ cihazı ile görüntülenip görüntülerden 3B dijital ve baskı modelleri elde edildi. 3B dijital modeller üzerinden omuz ile dirsek eklemlerine ait biyometrik ölçümleri gerçekleştirildi. Dişi ve erkek tavşanlara ait elde edilen veriler istatistiki açıdan değerlendirildi. Kesit kalınlığının düşük ve dedektör kalitesinin yüksek olması sebebiyle 3B eklem modellerindeki anatomik yapı oldukça detaylıydı. Üç boyutlu baskılama işlemi sonucunda üretilen 3B baskı modelleri son derece dayanıklı, kokusuz ve temizdi. 3B baskı modelleri ile 3B dijital modeller arasında herhangi bir anatomik farklılık gözlenmedi. Bu çalışmada laboratuvar tavşanlarına ait elde edilen anatomik ve morfometrik verilerin hem deneysel amaçlı ortopedik girişimlerde bulunan hem de klinik anatomi eğitimlerinde rol alan bilim insanlarına katkı sağlayacağı düşünülmektedir.

Anahtar sözcükler: Laboratuvar tavşanı, mikro bilgisayarlı tomografi, morfometri, ön bacak eklemleri, üç boyutlu rekonstrüksiyon.

\section{Introduction}

The New Zealand Rabbit (Oryctolagus cuniculus L.) is a species frequently preferred by scientists because it is used in many experimental studies. In terms of its anatomical features, it stands out as an animal model to be used in experimental orthopedic studies for joint areas in human medicine $(17,21)$. Digital x-ray (DR), computed tomography (CT), magnetic resonance imaging (MRI), and micro-computed tomography $(\mu \mathrm{CT})$ methods, which are diagnostic imaging techniques, are frequently used in the diagnosis and treatment of joint diseases. In addition, these methods used for diagnosis and treatment of diseases have an effective role in imaging healthy macroanatomical structures. Today, these methods, which are 
used very much in terms of both treatment and clinical anatomy education in human medicine, are also very useful in different areas of veterinary medicine (14).

In the late 1980s, Feldkamp and his colleagues were introduced $\mu \mathrm{CT}$ which is a unique imaging technique for the evaluation of bone morphology and microstructures in mice and other small animal models $(3,10)$. Today, $\mu \mathrm{CT}$ devices provide images with superior resolution. Since optical images provide real magnification in $\mu \mathrm{CT}$, even the smallest details of bone tissue can be clearly identified (12).

A series of 2-dimensional (2D) cross-sectional images are produced showing the anatomical relationship of the important structures of the body with medical imaging methods. 2D images are digitally stored in the international standard DICOM (Digital Imaging and Communications in Medicine) file format. This file format contains the necessary data about $3 \mathrm{D}$ reconstructed and sectional images. 3D models of the anatomical region are produced using software programs specially developed for DICOM files. With various software, the anatomical structure of the examined area can be clearly displayed, measured, highlighted, or partitioned separately at the same time $(7,23)$. In addition, $3 \mathrm{D}$ reconstructed images are used as a guide about the anatomy of the relevant region for surgical planning $(5,13,20)$. Traditionally, measurements on post-mortem anatomical samples have been the only method available to access linear, angular, and volumetric biometric data. Standard radiographic images are often used for linear biometric measurements. However, measurements on 2D radiographic images provide very limited information to researchers. Recently, accuracy and reliability of the measurements taken from $3 \mathrm{D}$ reconstructed models have become a curiosity for researchers. In the previous studies, 3D linear and angular anatomical measurements have been compared with measurements using digital calipers and goniometers (9). When the obtained data have been evaluated, it has been stated that the accuracy and reliability of $3 \mathrm{D}$ anatomical measurements are quite high $(2,8,13,19,28)$. It is known that 3D anatomical measurements can be used safely on skeletal structures, especially in the articular regions (9). 3D printing models of desired anatomical structure can be produced by using 3D digital models. 3D printing technology is very beneficial in areas such as tissue and organ construction, creation of customized prostheses, implants, and anatomical models (29). In addition, 3D models are very valuable educational materials for students, especially in radiology and anatomy education. 3D printing allows simpler visualization of complex anatomical structures (27). It has been stated that the cost of $3 \mathrm{D}$ printed anatomical specimens is quite convenient compared to the cost of cadaver traditionally used in educations. Using 3D samples instead of cadavers, which are difficult to obtain, provides a serious convenience in anatomy education $(1,6,18,28)$.

In this study, it was aimed to produce $3 \mathrm{D}$ digital and printing models from $\mu \mathrm{CT}$ images of healthy forelimb joints in laboratory rabbits and to evaluate the joints anatomically. Furthermore, we aimed to perform 3D morphometric measurements of the shoulder and elbow joints in female and male rabbits and to evaluate the obtained data statistically.

\section{Materials and Methods}

A total of 14 adults ( 7 females and 7 males) New Zealand Rabbits (Oryctolagus cuniculus L.) were used in the study. All procedures on animals were carried out in line with the approval of the ethics committee from the Ankara University Animal Experiments Local Ethics Committee (Approval number: 2017-5-32). The forelimbs of euthanized rabbits were removed from the body by appropriate dissection method. The imaging of the forelimbs was performed with the $\mu \mathrm{CT}$ device (Super Argus PET / CT, Sedecal, Spain). The forelimbs were placed and fixed on the bed in the medio-lateral position in accordance with their anatomical postures. The scanning process was performed from the middle level of the scapula to the distal ending of the distal phalanx with a thickness of $0.12 \mathrm{~mm}$. In the imaging process, $40 \mathrm{kV}$ and $140 \mu \mathrm{A}$ values were used at standard resolution. The obtained DICOM files were transferred to the 3D Slicer software (3D Slicer, 4.9.0 version, GitHub, San Francisco) and the images in transversal, frontal and sagittal planes were evaluated on the personal computer. 3D digital images of bone tissue were obtained by performing volume rendering and segmentation on the bone tissue window. Anatomical measurements of the shoulder and elbow joints were carried out over 3D reconstructed models in accordance with the relevant literatures $(24,25$, 31). The measurement process for each point was performed 3 times at different times and the final value was determined as the average of the whole measurement value. 3D printed models of forelimb joints were produced using a 3D printer (Anycubic i3 Mega FDM-printer). In the $3 \mathrm{D}$ printing process, 3D digital joint models of bone tissue were uploaded to the computer in the 'STL' file format. Then, the printing process was started by uploading files in the "STL" format to the $3 \mathrm{D}$ printer. This process was basically carried out using the Polylactic Acid (PLA) polymer in $\mathrm{x}, \mathrm{y}, \mathrm{z}$ coordinates. The use of anatomical terminology is based on Nomina Anatomica Veterinaria (22).

Descriptive statistics were calculated and presented as "Mean \pm Standard Error of Mean (SEM)". Before performing the statistical analysis, data was examined with Shapiro Wilk test for normality as parametric test assumptions. Data was analyzed using the GLM for 
Repeated Measures procedure of SPSS 14.01 (SPSS Inc., Chicago, IL, USA, License No: 9869264). The model included the gender as between subject factor and the side (left and right) as within subject factor, and the 2-way interaction term. Post hoc testing was carried out for the significant interaction term using simple effect analysis. A probability value of less than 0.05 was considered significant, unless otherwise noted.

\section{Results}

The anatomical structures on the 3D digital models obtained from the $\mu \mathrm{CT}$ images were quite detailed. On the 3D models of the shoulder joint, the joint cavity was quite evident, and the joint gap between cavitas glenoidalis and caput humeri was clearly observed. Tuberculum supraglenoidale and tuberculum infraglenoidale were prominent above the cranial and caudal edges of the cavitas glenoidalis, respectively. Caput humeri observed convexly on the proximal of the humerus was limited by the tuberculum minus and tuberculum majus in the craniomedial and craniolateral, respectively (Figure 1). On the 3D models of the elbow joint, the trochlea humeri was articulated with fovea capitis radii and olecranon in distal and caudal, respectively. Epicondylus medialis and epicondylus lateralis were in the form of a protrusion on the medial and lateral edges of the trochlea humeri. It was determined that incisura trochlearis supports trochlea humeri from the caudal edge and the two anatomical formations were quite compatible with each other (Figure 2). All bone structures of all joints were determined in detail on the 3D model of regio manus. Even small bone structures such as carpal bones were easily identified on the

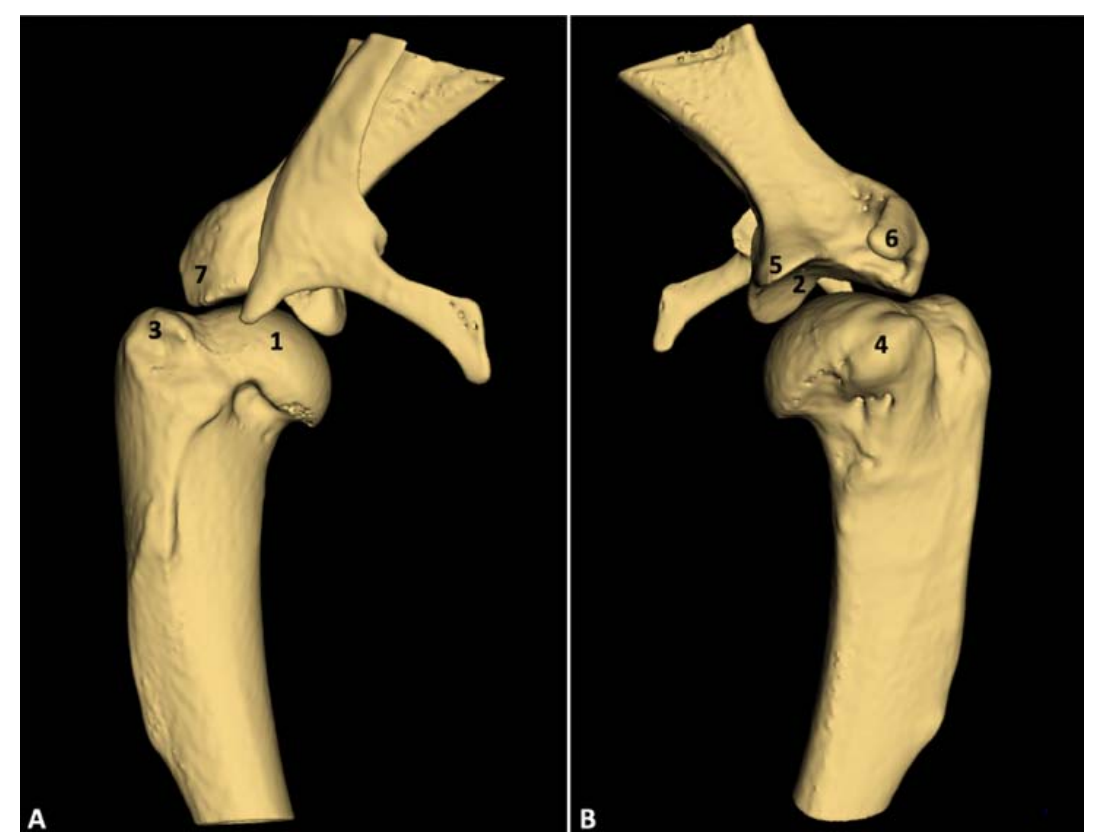

Figure 1. Lateral (A) and medial (B) view of the 3D digital model of the left shoulder joint. 1: Caput humeri; 2: Cavitas glenoidalis; 3: Tuberculum majus; 4: Tuberculum minus; 5: Tuberculum infraglenoidale; 6: Processus coracoideus; 7: Tuberculum supraglenoidale.

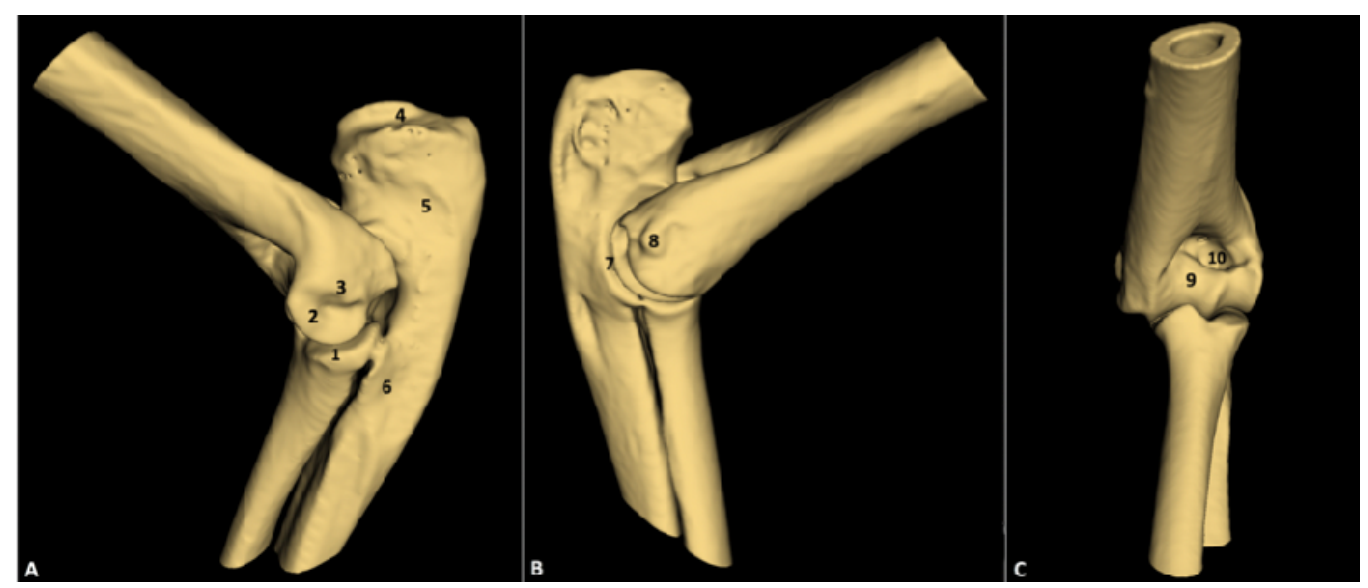

Figure 2. Lateral (A), medial (B) and cranial (C) view of the 3D digital model of the left elbow joint. 1: Fovea capitis radii; 2: Capitulum humeri; 3: Epicondylus lateralis; 4: Tuber olecrani; 5: Olecranon; 6: Corpus ulnae; 7: Incisura trochlearis; 8: Epicondylus medialis; 9 : Trochlea humeri; 10: Fossa coronoidea. 
3D models (Figure 3). Articulatio radioulnaris distalis was formed by the medial surface of the processus styloideus lateralis and incisura ulnaris. While the distal of the radius, os carpi radiale and os carpi intermedium were added to the form of the articulatio radiocarpeae, the distal of the ulna, os carpi ulnare, and os carpi accessorium were added to the form of the articulatio ulnocarpeae. In the distal, os carpi radiale, os carpi intermedium, and os carpi ulnare were jointed with os carpale I and os carpale II, os carpale III and os carpale IV, os carpale IV, respectively. When the joints of the carpal bones located in the distal row with the bones in the distal were examined, the bones involved in the structures of the joints were: os carpale I with os metacarpale I and os metacarpale II; os carpale II with os metacarpale II; os carpale III with os carpi centrale and os metacarpale II; os carpi centrale with os metacarpale III; os carpale IV with os metacarpale III, os metacarpale IV and os metacarpale $\mathrm{V}$. On the palmar face of the articulatio metacarpophalangea, there was a pair of proximal sesamoid bones, one axial and the other abaxial. Likewise, there was a distal sesamoid bone on the palmar face of the articulatio interphalangea distalis (Figure 3).

Morphometric bone measurements of shoulder and elbow joints were provided over 3D models. Measurement points were indicated in Figure 4. The values of the measurement results were given in Table 1 . There was no statistically difference between the right and left values of the female and male animals in the following measurements; the proximal width of the humerus (HPW), the lateral width of the proximal radius (PRLW), the medial width of the proximal radius (PRMW), the distal width of the humerus (HDW), the width of the processus coronoideus (PCW), the smallest depth of the olecranon (OSD), the depth of the processus anconeus (PAD). At the same time, the difference between the genders for the right and left values was statistically insignificant $(\mathrm{P}>0.05)$. For the width of cavitas glenoidalis (CGW), the difference between the right and left values of female and male rabbits was statistically insignificant $(\mathrm{P}>0.05)$. However, it was determined that the right and left values were higher in male rabbits than in females, and this difference was statistically significant $(\mathrm{P}<0.05)$. For the depth of tuber olecrani (TOD), the left measurement values of females and males were higher than the right measurement values. The difference between values was found statistically important $(\mathrm{P}<0.05)$. When the right and left measurement values were compared between the genders, it was determined that the values were quite close to each other. In the measurements of the width of epicondylus lateralis (ELW), the difference between the right and left values of the female and male was statistically insignificant $(\mathrm{P}>0.05)$. In addition, the fact that the left measurement value of males was higher than the females was statistically significant $(\mathrm{P}<0.05)$. For the width of the proximal radius (RPW), the difference between the right and left values of females and males was statistically unimportant $(\mathrm{P}>0.05)$. However, it was determined that right and left values were higher in male rabbits than in females, and this difference was statistically significant $(\mathrm{P}<0.05)$. For the width of epicondylus medialis (EMW), the difference between the right and left values in females and males was found statistically important $(\mathrm{P}<0.05)$. The right values for both genders were higher than the left values. However, when the right and left measurement values were compared between genders, the difference between the values was found statistically insignificant $(\mathrm{P}>0.05)$.

Figure 3. Dorsal (A) and palmar (B) view of the 3D digital model of the left regio manus. 1: Radius; 2 : Ulna; 3: Os carpi radiale; 4: Os carpi intermedium; 5: Os carpi ulnare; 6: Os carpi accessorium; 7: Os carpale IV; 8: Os carpi centrale; 9: Os carpale III; 10: Os carpale II; 11: Os carpale I; 12: Os metacarpale I; 13: Os metacarpale II; 14: Os metacarpale III; 15: Os metacarpale IV; 16: Os metacarpale V; 17: Phalanx proximalis digiti I; 18: Phalanx proximalis digiti II; 19: Phalanx proximalis digiti III; 20: Phalanx proximalis digiti IV; 21: Phalanx proximalis digiti $\mathrm{V} ; 22$ : Phalanx media digiti II; 23: Phalanx media digiti III; 24: Phalanx media digiti IV; 25: Phalanx media digiti V; 26: Phalanx distalis digiti I; 27: Phalanx distalis digiti II; 28: Phalanx distalis digiti III; 29: Phalanx distalis digiti IV; 30: Phalanx distalis digiti V; 3132: Os sesamoideum proximale; 33: Os sesamoideum distale.

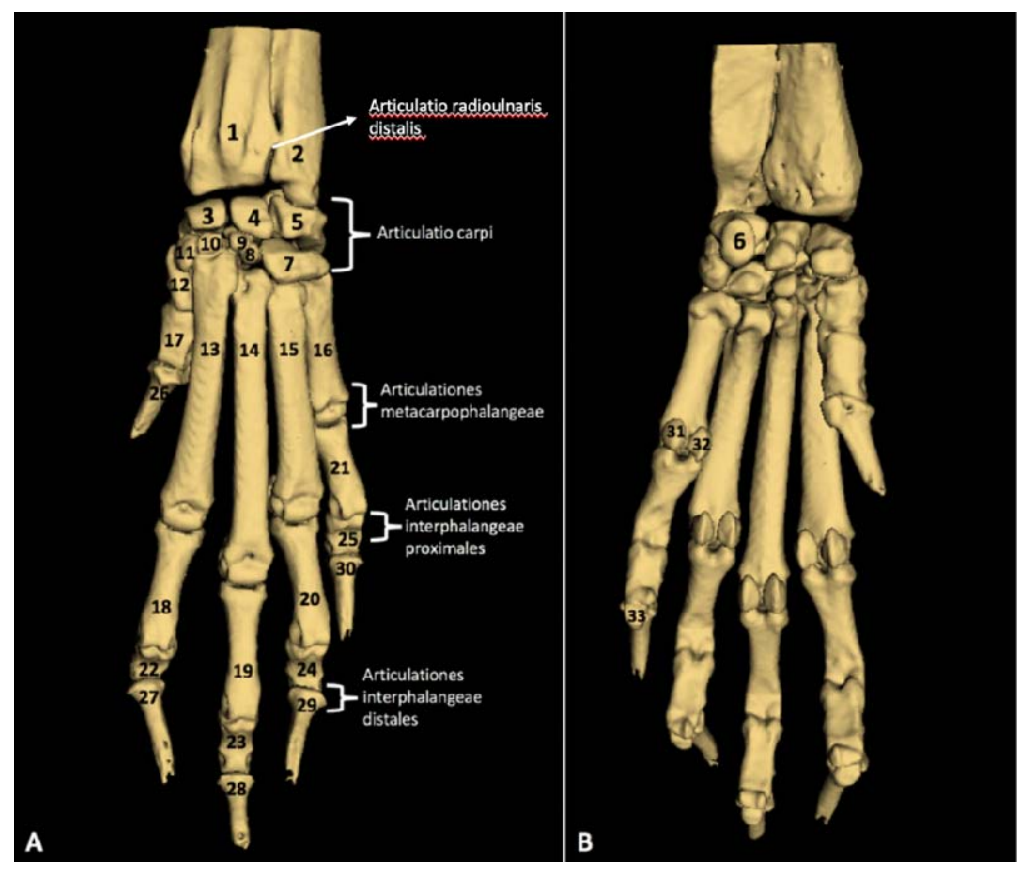


Table 1. Statistical data of 3D morphometric measurement values.

\begin{tabular}{|c|c|c|c|c|c|c|}
\hline \multirow{2}{*}{ Measurement } & \multirow[t]{2}{*}{ Gender } & \multicolumn{2}{|c|}{ Side } & \multicolumn{3}{|c|}{$\mathbf{P}$} \\
\hline & & Right (mm) & Left (mm) & $\begin{array}{c}\text { Gender } \\
\text { (G) }\end{array}$ & Side (S) & $G * S$ \\
\hline \multirow[t]{2}{*}{ HPW } & $\mathrm{F}$ & $13.90 \pm 0.130$ & $13.85 \pm 0.081$ & 0.591 & 0.503 & 0.902 \\
\hline & $\mathrm{M}$ & $13.97 \pm 0.130$ & $13.93 \pm 0.081$ & & & \\
\hline \multirow[t]{2}{*}{ CGW } & $\mathrm{F}$ & $9.13 \pm 0.161^{\mathrm{B}}$ & $8.87 \pm 0.186^{\mathrm{B}}$ & 0.045 & 0.598 & 0.280 \\
\hline & $\mathrm{M}$ & $9.39 \pm 0.161^{\mathrm{A}}$ & $9.48 \pm 0.186^{\mathrm{A}}$ & & & \\
\hline \multirow[t]{2}{*}{ TOD } & $\mathrm{F}$ & $8.33 \pm 0.034^{\mathrm{a}}$ & $8.54 \pm 0.082^{b}$ & 0.966 & 0.036 & 0.304 \\
\hline & $\mathrm{M}$ & $8.39 \pm 0.034^{\mathrm{a}}$ & $8.47 \pm 0.082^{b}$ & & & \\
\hline \multirow[t]{2}{*}{ ELW } & $\mathrm{F}$ & $7.29 \pm 0.116^{\mathrm{B}}$ & $7.09 \pm 0.104^{\mathrm{B}}$ & 0.061 & 0.459 & 0.039 \\
\hline & $\mathrm{M}$ & $7.43 \pm 0.116^{\mathrm{A}}$ & $7.53 \pm 0.104^{\mathrm{A}}$ & & & \\
\hline \multirow[t]{2}{*}{ PRLW } & $\mathrm{F}$ & $4.86 \pm 0.158$ & $5.02 \pm 0.162$ & 0.779 & 0.957 & 0.250 \\
\hline & $\mathrm{M}$ & $4.96 \pm 0.158$ & $4.79 \pm 0.162$ & & & \\
\hline \multirow[t]{2}{*}{ HDW } & $\mathrm{F}$ & $10.65 \pm 0.116$ & $10.57 \pm 0.107$ & 0.256 & 0.143 & 0.732 \\
\hline & $\mathrm{M}$ & $10.85 \pm 0.116$ & $10.71 \pm 0.107$ & & & \\
\hline \multirow[t]{2}{*}{ RPW } & $\mathrm{F}$ & $7.58 \pm 0.092^{\mathrm{B}}$ & $7.39 \pm 0.079^{\mathrm{B}}$ & 0.005 & 0.161 & 0.445 \\
\hline & $\mathrm{M}$ & $7.81 \pm 0.092^{\mathrm{A}}$ & $7.75 \pm 0.079^{A}$ & & & \\
\hline \multirow[t]{2}{*}{ EMW } & $\mathrm{F}$ & $7.27 \pm 0.101^{\mathrm{a}}$ & $7.11 \pm 0.078^{b}$ & 0.099 & 0.016 & 0.254 \\
\hline & $\mathrm{M}$ & $7.44 \pm 0.101^{\mathrm{a}}$ & $7.38 \pm 0.078^{b}$ & & & \\
\hline \multirow[t]{2}{*}{ PRMW } & $\mathrm{F}$ & $4.49 \pm 0.143$ & $4.42 \pm 0.111$ & 0.638 & 0.204 & 0.550 \\
\hline & $\mathrm{M}$ & $4.62 \pm 0.143$ & $4.43 \pm 0.111$ & & & \\
\hline \multirow[t]{2}{*}{ PCW } & $\mathrm{F}$ & $6.54 \pm 0.064$ & $6.50 \pm 0.086$ & 0.204 & 0.574 & 0.933 \\
\hline & M & $6.65 \pm 0.064$ & $6.62 \pm 0.086$ & & & \\
\hline \multirow[t]{2}{*}{ OSD } & $\mathrm{F}$ & $7.90 \pm 0.081$ & $7.98 \pm 0.058$ & 0.453 & 0.299 & 0.993 \\
\hline & $\mathrm{M}$ & $7.95 \pm 0.081$ & $8.03 \pm 0.058$ & & & \\
\hline \multirow{2}{*}{ PAD } & $\mathrm{F}$ & $8.57 \pm 0.048$ & $8.61 \pm 0.044$ & 0.904 & 0.674 & 0.102 \\
\hline & $\mathrm{M}$ & $8.63 \pm 0.048$ & $8.57 \pm 0.044$ & & & \\
\hline
\end{tabular}

a,b: Different letters on the same line indicate statistically significant difference $(\mathrm{P}<0.05)$; ${ }^{\mathrm{A}, \mathrm{B}}$ : Different letters on the same column indicate a statistically significant difference $(\mathrm{P}<0.05)$. F: Female; M: Male. HPW: Proximal width of the humerus; CGW: Width of the cavitas glenoidalis; TOD: Depth of the tuber olecrani; ELW: Width of the epicondylus lateralis; PRLW: Lateral width of the proximal radius; HDW: Distal width of the humerus; RPW: Width of the proximal radius; EMW: Width of the epicondylus medialis; PRMW: Medial width of the proximal radius; PCW: Width of the processus coronoideus; OSD: The smallest depth of the olecranon; PAD: Depth of the processus anconeus.

Figure 4. Morphometric measurement points taken over 3D models. A: Proximal width of the humerus (HPW); B: Width of the cavitas glenoidalis (CGW); C: Depth of the tuber olecrani (TOD); D: Width of the epicondylus lateralis (ELW); E: Lateral width of the proximal radius (PRLW); F: Distal width of the humerus (HDW); G: Width of the proximal radius (RPW); $\mathrm{H}$ : Width of the epicondylus medialis (EMW); I: Medial width of the proximal radius (PRMW); J: Width of the processus coronoideus (PCW); K: The smallest depth of the olecranon (OSD); L: Depth of the processus anconeus (PAD).

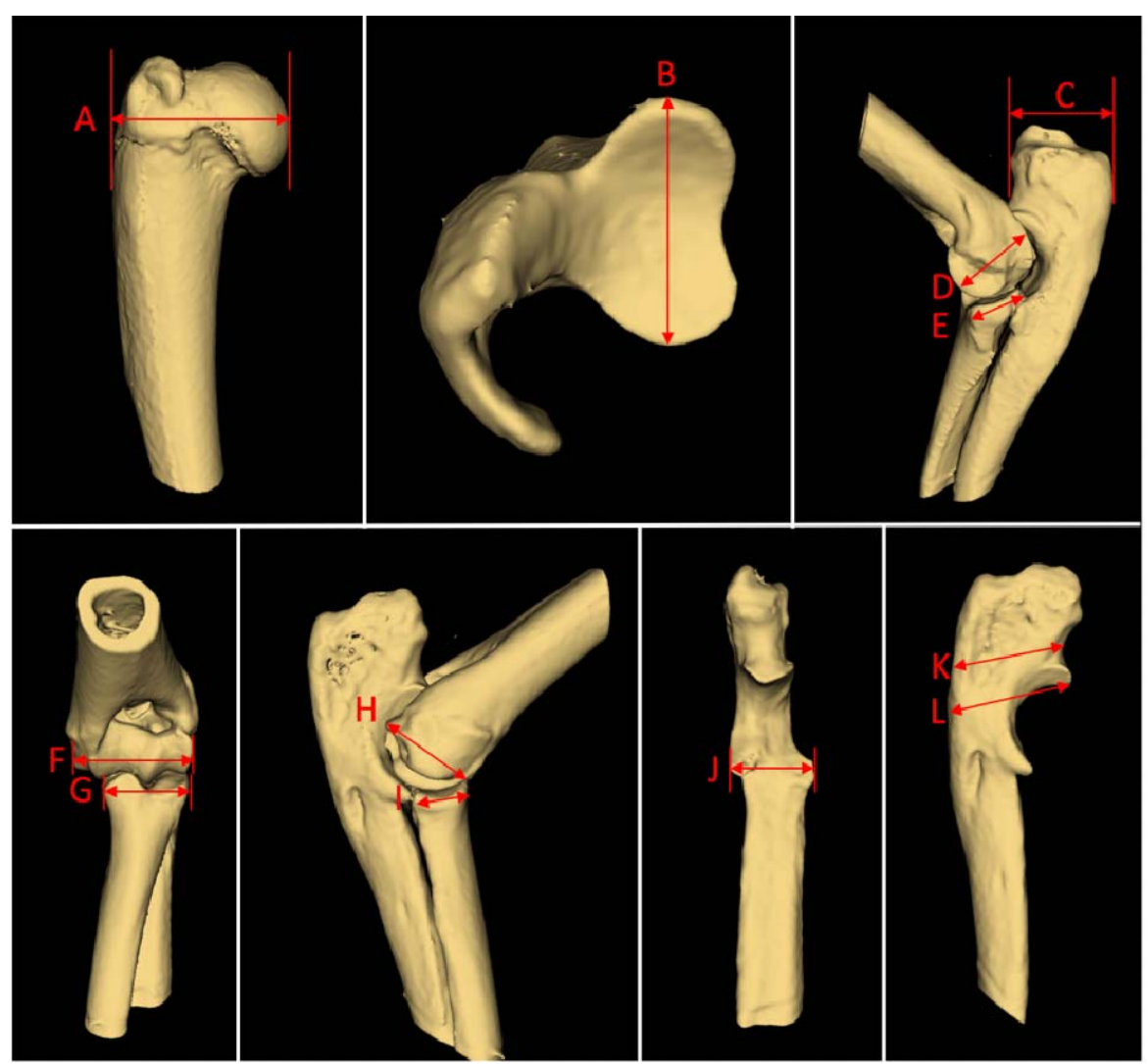




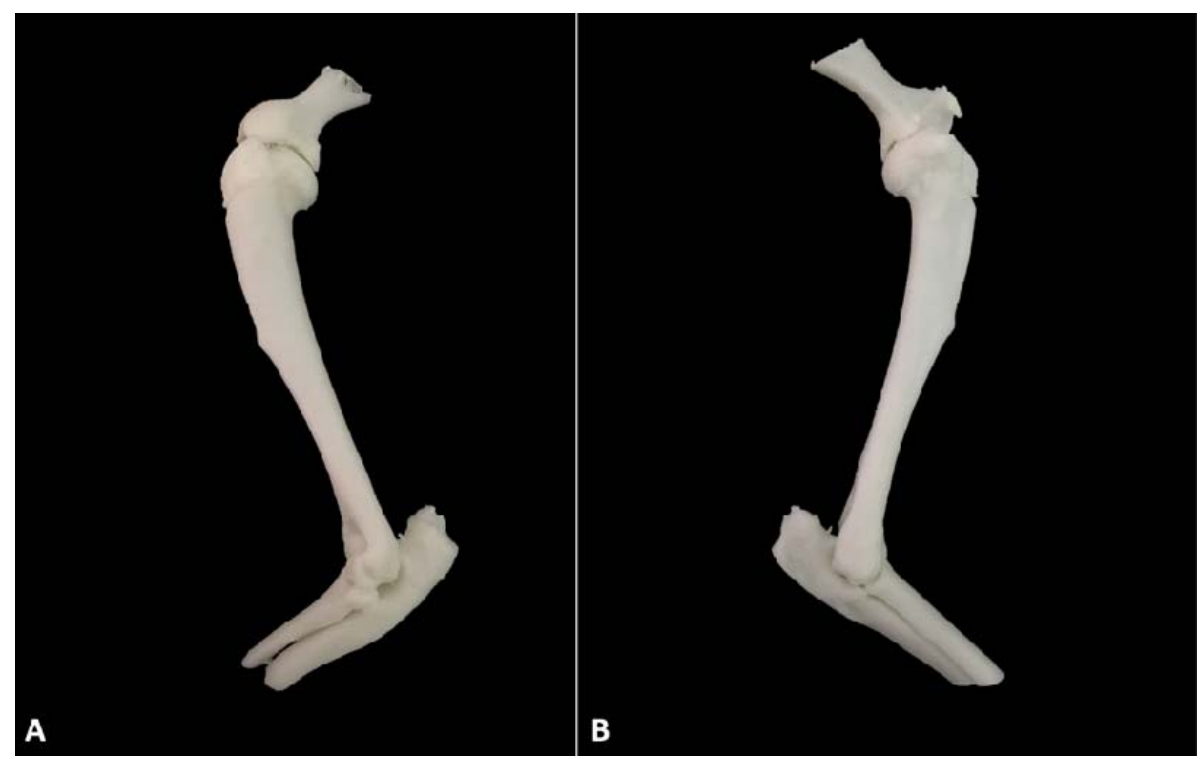

Figure 5. Lateral (A) and medial (B) view of the 3D printed model of the left shoulder and elbow joints.

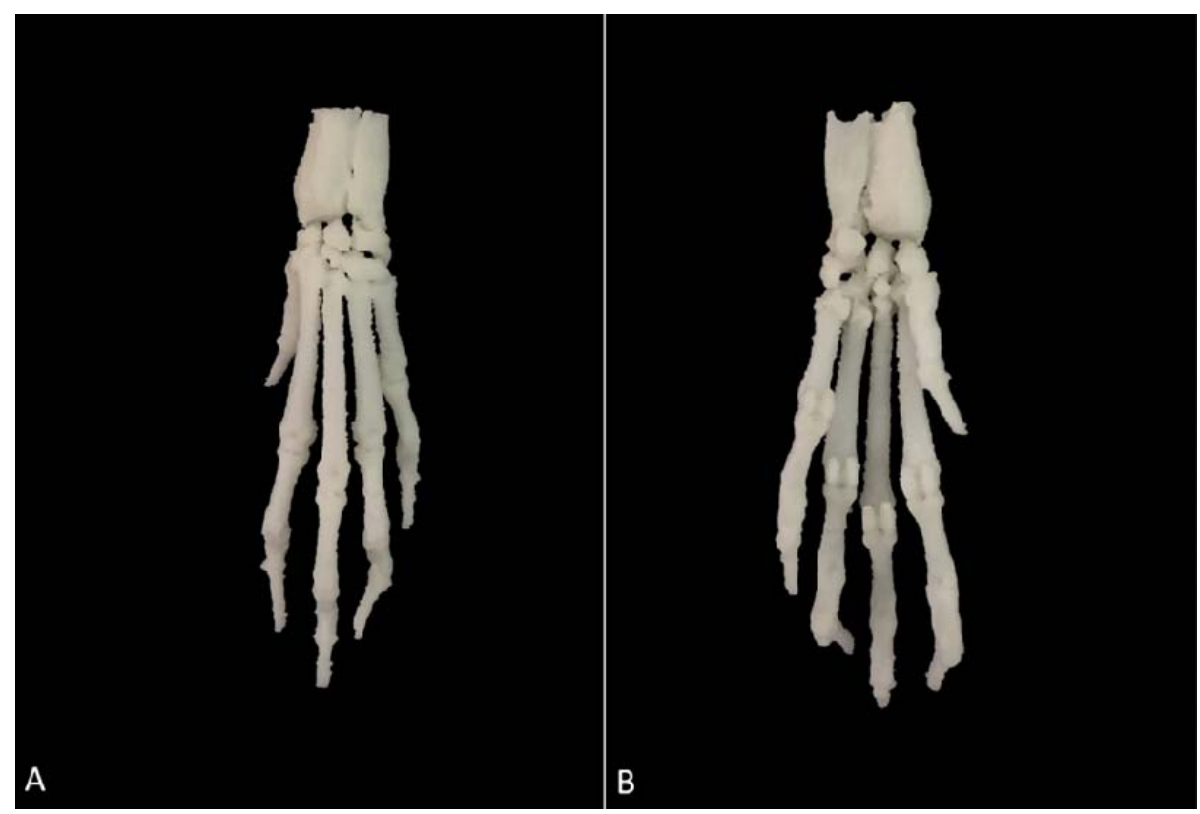

Figure 6. Dorsal (A) and palmar (B) view of the 3D printed model of the left regio manus.

As a result of the $3 \mathrm{D}$ printing process, durable, odorless, clean, and realistic $3 \mathrm{D}$ printing models were produced. No anatomical differences were observed between the $3 \mathrm{D}$ printing models produced and the $3 \mathrm{D}$ digital models in the 'STL' file format that were loaded on the $3 \mathrm{D}$ printer before the printing process. Since the printing materials were quite small, the supporting texture was used in the printing process. Therefore, it was necessary to clean the support tissue consisting of thermoplastic polymer around the samples produced after printing. It was determined that the structures belonging to the bone tissue on the joint areas on the printed models retain their anatomical features. It was observed that the bone structures boundaries of all joint regions, especially the small carpal bones, were easily distinguishable from each other (Figures 5 and 6).

\section{Discussion and Conclusion}

It is possible to design $3 \mathrm{D}$ digital anatomical models from 2D cross-sectional images using various commercial software programs. The production mechanisms of $3 \mathrm{D}$ models from 2D images have been explained by using different software programs (4). With the 3D Slicer software program used in this study, reformat images were created in sagittal and frontal planes using DICOM files containing transversal $\mu \mathrm{CT}$ sectional images. Segmentation of bone tissue was performed from the sectional images. As a result of the segmentation process, 
3D digital models were successfully visualized. In addition, the fact that the 3D Slicer program could be accessed free of charge from the internet environment has significantly reduced the cost of this research.

$3 \mathrm{D}$ printing technology has many benefits in anatomy education. Among the reasons of the increase in the interest of scientists researching in the medical field to this technology are the difficulties of finding cadavers and the formaldehyde used for fixation and storage of tissues is very harmful to human health $(11,16)$. In this study, it is thought that the production of bone models with 3D printing technology will reduce the use of cadaver, which is constantly required in the preparation of organic bone samples. It has been stated that $3 \mathrm{D}$ printing models can be used safely by both educators and students, and with the help of printing models, quite complex anatomical structures can be visualized simply $(16,26)$. In this study, $3 \mathrm{D}$ printed bone models were produced from $\mu \mathrm{CT}$ images of joint regions. Especially the anatomical structures and neighbourhoods of very small carpal bones in articulatio carpi were easily determined on models. Li et al. (16) have produced $3 \mathrm{D}$ printing models of some cattle bones in their study. They have evaluated the effectiveness of these printed models in anatomy education with the survey on students. The vast majority of the students who participated in the survey stated that the anatomical structures in 3D printing models were not different from those of organic bone samples, and the models were odorless, light, and durable. 3D printing models obtained in this study were also found to be very light, odorless, durable, and clean. When 3D printing and digital models were compared, there was no anatomical difference between them.

It is known that $3 \mathrm{D}$ morphometric studies of the rabbit's forelimb skeleton structures belong only to antebrachium (24). 3D digital models of antebrachium have been carried out over CT images. In addition, Pazvant and Kahvecioğlu (25) have performed the measurements over the forelimb long bones of rabbits with the traditionally used digital caliper method. However, in the literature search, no detailed morphometric study on the shoulder and elbow joints of rabbits was found. In our research, the $\mu \mathrm{CT}$ technique was used to produce more detailed 3D anatomical models and to perform detailed biometric measurements over the 3D models. The bone tissue on the images was segmented sectionally by using the "paint" and "level tracing" commands using the 3D Slicer software program. After the segmentation process, the $3 \mathrm{D}$ models obtained were rotated in the desired way and the measurements of shoulder and elbow joints were easily performed.

Pazvant and Kahvecioğlu (25) have investigated the homotypic variations of the forelimb and hindlimb long bones of rabbits in their study. They have provided morphometric measurements with the help of digital calipers over the real bone samples they obtained as a result of the maceration process. In the measurements of the proximal width of the humerus, the right and left mean values of females have been determined as $13.87 \mathrm{~mm}$ and $13.82 \mathrm{~mm}$, respectively. For the measurements of male rabbits, the right and left values have been calculated as $13.67 \mathrm{~mm}$ and $13.66 \mathrm{~mm}$, respectively. In the measurements of the distal width of the humerus, the right mean values of the females and males have been specified as $10.67 \mathrm{~mm}$ and $10.75 \mathrm{~mm}$, and the left mean values have been determined as $10.88 \mathrm{~mm}$ and $11.32 \mathrm{~mm}$, respectively. In our study, it was determined that the $3 \mathrm{D}$ morphometric measurement data obtained from the proximal and distal width of the humerus were parallel to the data in the literature, and there was no statistically difference between the genders and the right and left data (Table 1). In the literature, it has been stated that there is no statistical difference between the genders and the right and left values in the genders for the proximal width of the radius. In our study, the difference between the right and left values of females and males was statistically insignificant. However, it was determined that the right and left values were higher in male rabbits than in females, and this difference was statistically significant (Table 1). Moreover, all measurement values for this region were found to be higher than in the literature. This differentiation is thought to be due to the difference in body mass. Morphometric values of the depth of olecranon in the related literature were similar to the values obtained in our research. Unlike the literature, the left measurement values of the male and female obtained in our study were higher than the right measurement values. The difference between data was statistically significant (Table 1).

Özkadif et al. (24) have produced 3D models of multidetector-CT images of antebrachium in rabbits and provided morphometric measurements on models. They have compared the measured values statistically between female and male animals. The difference between the right and left values of females and males has been found statistically insignificant in the measurements of the proximal width of the radius. However, the right and left measurement values of male rabbits have been higher than that of females, and this difference has been found statistically significant. In our study, 3D models with high resolution and anatomically more detailed were produced from $\mu \mathrm{CT}$ images. All the measured values of proximal width of the radius were found higher than the values specified in the literature. This differentiation is thought to be due to the fact that the bone margins are more clear in the anatomical models we have obtained and therefore there is a difference in measurement points. In parallel with the literature, it was determined that the right and left 
values were higher in male rabbits than in females, and this difference was statistically significant (Table 1).

In this study, it has been determined that $3 \mathrm{D}$ digital anatomical models can be easily produced using special software programs, and 3D printing models can be designed simply by using $3 \mathrm{D}$ printers. It has been thought that $3 \mathrm{D}$ technology can be used in areas such as veterinary anatomy, veterinary surgery, and radiology. It has been anticipated that the use of 3D digital and printing models in anatomy education will considerably reduce the use of cadavers and harmful chemicals such as formaldehyde. It has been understood that morphometric measurements made on organic bone samples can be also easily performed on 3D models.

In conclusion, it is thought that the data obtained in this study will benefit the fields of veterinary anatomy, surgery, and radiology. It is also anticipated that this study will bring a modern approach to the field of veterinary anatomy and will be an useful resource for scientists who will research on the forelimb joints of laboratory rabbits.

\section{Acknowledgements}

This study was prepared from $\mathrm{PhD}$ thesis entitled "Evaluation of the thoracic limb joints in the New Zealand Rabbit (Oryctolagus cuniculus L.) using different techniques" of the first author. The authors would like to thank Dr. Ufuk KAYA from the Department of Biostatistics, Faculty of Veterinary Medicine, Hatay Mustafa Kemal University for the statistical analysis. We also thank Trifolium Company for 3D printing process.

\section{Financial Support}

This study was financially supported by Ankara University Scientific Research Projects Unit (Project no: 17L0239013).

\section{Ethical Statement}

This study was approved by the Ankara University Animal Experiments Local Ethics Committee (Approval number: 2017-5-32).

\section{Conflict of Interest}

The authors declared that there is no conflict of interest

\section{References}

1. Bakıcı C, Akgün RO, Oto C (2019): The applicability and efficiency of 3 dimensional printing models of hyoid bone in comparative veterinary anatomy education. Vet Hekim Der Derg, 90, 71-75.

2. Berco M, Rigali PH, Miner RM, et al (2009): Accuracy and reliability of linear cephalometric measurements from cone-beam computed tomography scans of a dry human skull. Am J Orthod Dentofac, 136, 1-9.
3. Bouxsein ML, Boyd SK, Christiansen BA, et al (2010): Guidelines for assessment of bone microstructure in rodents using micro-computed tomography. J Bone Miner Res, 25, 1468-1486.

4. Brazina D, Fojtik R, Rombova Z (2014): 3 D visualization in teaching anatomy. Procedia Soc Behav Sci, 143, 367371.

5. Estai M, Bunt $\mathbf{S}$ (2016): Best teaching practices in anatomy education: A critical review. Ann Anat, 208, 151-157.

6. Fasel JHD, Aguiar D, Kiss-Bodolay D, et al (2016): Adapting anatomy teaching to surgical trends: a combination of classical dissection, medical imaging, and 3D-printing technologies. Surg Radiol Anat, 38, 361-367.

7. Freitas EP, Noritomi PY, Silva JVL (2011): Use of Rapid Prototyping and 3D Reconstruction in Veterinary Medicine. In: ME Hoque (Ed), Advanced Applications of Rapid Prototyping Technology in Modern Engineering. InTech, China.

8. Gribel BF, Gribel MN, Frazao DC, et al (2011): Accuracy and reliability of craniometric measurements on lateral cephalometry and $3 D$ measurements on CBCT scans. Angle Orthod, 81, 26-35.

9. Jamali AA, Deuel C, Perreira A, et al (2007): Linear and angular measurements of computer-generated models: Are they accurate, valid, and reliable? Comput Aided Surg, 12, 278-285.

10. Jiang Y, Zhao J, White DL, et al (2000): Micro CT and micro MR imaging of $3 D$ architecture of animal skeleton. $\mathrm{J}$ Musculoskel Neuron Interact, 1, 45-51.

11. Jones DG (2019): Three-dimensional printing in anatomy education: Assessing potential ethical dimensions. Anat Sci Educ, 12, 435-443.

12. Keleş A, Alçin H (2015): Mikro bilgisayarlı tomografi ve endodontik araştırmalardaki yeri. Türkiye Klinikleri J Endod-Special Topics, 1, 32-39.

13. Kim M, Huh KH, Yi WJ, et al (2012): Evaluation of accuracy of $3 D$ reconstruction images using multi-detector CT and cone-beam CT. Imaging Sci Dent, 42, 25-33.

14. Labruyere J, Schwarz T (2013): CT and MRI in veterinary patients: an update on recent advances. In Pract, 35, 546563.

15. Lagravere MO, Carey J, Toogood RW, et al (2008): Three- dimensional accuracy of measurements made with software on cone-beam computed tomography images. Am J Orthod Dentofac, 134, 112-116.

16. Li F, Liu C, Song X, et al (2018): Production of accurate skeletal models of domestic animals using threedimensional scanning and printing technology. Anat Sci Educ, 11, 73-80.

17. Martini L, Fini M, Giavaresi G, et al (2001): Sheep model in orthopedic research: A literature review. Comp Med, 51, 292- 299.

18. Mitsouras $\mathbf{D}$, Liacouras $\mathbf{P}$, Imanzadeh A, et al (2015): Medical $3 D$ printing for the radiologist. Radiographics, $\mathbf{3 5}$, 1965- 1988.

19. Moreira CR, Sales MAO, Lopes PML, et al (2009): Assessment of linear and angular measurements on threedimensional cone- beam computed tomographic images. Oral Surg Oral Med Oral Pathol Oral Radiol Endod, 108, 430-436. 
20. Murgitroyd E, Madurska M, Gonzalez J, et al (2015): $3 D$ digital anatomy modelling - Practical or pretty? The Surgeon, 13, 177-180.

21. Naff KA, Craig S (2012): The Domestic Rabbit, Oryctolagus Cuniculus: Origins and History. In: MA Suckow, KA Stevens, PP Wilson (Eds), The Laboratory Rabbit, Guinea Pig, Hamster and Other Rodents. Academic Press, London.

22. Nomina Anatomica Veterinaria (2017): Prepared by the international committes on veterinary gross anatomical nomenclature and authorized by the general assambly of the world association of veterinary anatomists (6th ed.). Hanover, Germany, Ghent, Belgium, Columbia, MO, Rio de Janeiro, Brazil: The Editorial Committee.

23. Özkadif S, Eken E (2015): Contribution of virtual anatomic models to medical education. Atatürk Üniversitesi Vet Bil Derg, 10, 46-54.

24. Özkadif S, Eken E, Beşoluk K, et al (2015): Threedimensional reconstruction of New Zealand rabbit antebrachium by multidetector computed tomography. Iran J Vet Res, 16, 205-209.

25. Pazvant G, Kahvecioğlu KO (2009): Tavşanlarda ön ve arka bacak uzun kemiklerinin homotipik varyasyonlart üzerinde araştırmalar. İstanbul Üniv Vet Fak Derg, 35, 2339.

26. Preece D, Williams SB, Lam R, et al (2013): "Let's Get Physical": Advantages of a physical model over $3 D$ computer models and textbooks in learning imaging anatomy. Anat Sci Educ, 6, 216-224.

27. Pujol S, Baldwin M, Nassiri J, et al (2016): Using $3 D$ modeling techniques to enhance teaching of difficult anatomical concepts. Acad Radiol, 4, 507-516.

28. Remzi OA, Caner B, Okan E, et al (2019): Accuracy and Reliability of Measurements Obtained from 3-Dimensional Rabbit Mandible Model: A Micro-Computed Tomography Study. Acta Vet-Beograd, 69, 192-200.

29. Rengier F, Mehndiratta A, Tengg-Kobligk $H$, et al (2010): 3D printing based on imaging data: review of medical applications. Int J Cars, 5, 335-341.

30. Ventola CL (2014): Medical applications for $3 D$ printing: Current and projected uses. Pharm Ther, 39, 704-711.

31. Von Den Driesch A (1976): A Guide to the Measurement of Animal Bones from Archaeological Sites. Pea Body Museum Bulletin 1. Harward University, Massachusetts. 